Research article

\title{
Elevated nerve growth factor and neurotrophin-3 levels in cerebrospinal fluid of children with hydrocephalus Frederike Hochhaus ${ }^{1,3}$, Petra Koehne ${ }^{1}$, Christoph Schäper ${ }^{2}$, Otfrid Butenandt ${ }^{3}$, Ursula Felderhoff-Mueser ${ }^{* 1}$, Elfride Ring-Mrozik ${ }^{4}$, Michael Obladen ${ }^{1}$ and Christoph Bührer ${ }^{1}$
}

Address: ${ }^{1}$ Neonatology, Charité, Campus Virchow Klinikum, Humboldt-University, Berlin, Germany, ${ }^{2}$ Clinical Immunology, Charité, Campus Virchow Klinikum, Humboldt-University, Berlin, Germany, ${ }^{3}$ Dr. von Haunersches Kinderspital, Ludwig-Maximilians-University, Munich, Germany and ${ }^{4}$ Department of Pediatric Surgery, Klinikum Ingolstadt, Ingolstadt, Germany

E-mail: Frederike Hochhaus - frederike.hochhaus@charite.de; Petra Koehne - petra.koehne@charite.de;

Christoph Schäper - christoph.schaeper@charite.de; Otfrid Butenandt - otfrid.butenandt@lrz.uni-muenchen.de; Ursula Felderhoff-

Mueser* - ursula.felderhoff@charite.de; Elfride Ring-Mrozik - frederike.hochhaus@charite.de;

Michael Obladen - michael.obladen@charite.de; Christoph Bührer - christoph.buehrer@charite.de

*Corresponding author

Published: 24 August 200I

Received: 21 May 2001

BMC Pediatrics 200I, I:2

Accepted: 24 August 2001

This article is available from: http://www.biomedcentral.com//47/-243I///2

(C) 200 I Hochhaus et al; licensee BioMed Central Ltd. Verbatim copying and redistribution of this article are permitted in any medium for any noncommercial purpose, provided this notice is preserved along with the article's original URL. For commercial use, contact info@biomedcentral.com

\begin{abstract}
Background: Elevated intracranial pressure (ICP) resulting from impaired drainage of cerebrospinal fluid (CSF) causes hydrocephalus with damage to the central nervous system. Clinical symptoms of elevated intracranial pressure (ICP) in infants may be difficult to diagnose, leading to delayed treatment by shunt placement. Until now, no biochemical marker of elevated ICP has been available for clinical diagnosis and monitoring. In experimental animal models, nerve growth factor (NGF) and neurotrophin-3 (NT-3) have been shown to be produced by glial cells as an adaptive response to hypoxia. We investigated whether concentrations of NGF and NT-3 are increased in the CSF of children with hydrocephalus.
\end{abstract}

Methods: NGF was determined in CSF samples collected from 42 hydrocephalic children on 65 occasions (taps or shunt placement surgery). CSF samples obtained by lumbar puncture from 22 children with suspected, but unconfirmed bacterial infection served as controls. Analysis was performed using ELISA techniques.

Results: NGF concentrations in hydrocephalic children were over 50 -fold increased compared to controls (median 225 vs $4 \mathrm{pg} / \mathrm{mL}, \mathrm{p}<0.000 \mathrm{I}$ ). NT-3 was detectable $(>\mathrm{I} \mathrm{pg} / \mathrm{mL}$ ) in $|4 / 3|$ hydrocephalus samples at $2-5 I \mathrm{pg} / \mathrm{mL}$ but in none of II control samples $(p=0.007)$.

Conclusion: NGF and NT-3 concentrations are increased in children with hydrocephalus. This may represent an adaptive response of the brain to elevated ICP.

\section{Background}

Hydrocephalus can be caused by a variety of unrelated conditions, such as intraventricular hemorrhage, menin- gitis, trauma, tumours, or may be associated with spinal dysraphism or other cerebral malformations. Abnormal ventricular accumulation of cerebrospinal fluid (CSF), 
due to obstruction of flow, inadequate absorption, and/ or excessive production, results in elevated intracranial pressure (ICP) and ventricular dilation. Patients with persistent hydrocephalus require surgical placement of a ventricular shunt to drain excessive CSF, thereby avoiding further hypoxic-ischaemic brain damage. However, shunts often malfunction due to blockage and/or infection, subjecting the patients to intermittent episodes of elevated ICP. While the chronic hypoxia and ischaemia resulting from elevated ICP causes progressive tissue damage, $[1,2]$ little is known about adaptive responses of the brain.

The neurotrophins nerve growth factor (NGF) and neurotrophin-3 (NT-3) play important roles in the survival, differentiation and synaptogenesis of neurons, especially in the developing brain [3]. Elevated NGF concentrations have been found in the cortices of congenitally hydrocephalic H-Tx rats during the progression of hydrocephalus [4]. After transient cerebral ischaemia with or without subsequent hypoglycemia, a pronounced increase of NGF mRNA has been observed in rats, while NT-3 may be temporarily depressed [5]. After traumatic brain injury, a sustained NGF protein increase has also been found in the cortices of rats and in CSF of individual patients related to the severity of head injury $[6,7]$. NT-3 has been reported to be increased in the CSF from patients with bacterial meningitis $[8,9]$ and in four infants undergoing shunt placement for hydrocephalus [9]. Hypothesising that changes of neurotrophin production in response to elevated ICP may be reflected in altered CSF concentrations of NGF and NT-3, we set out to measure these neurotrophins in children who underwent ventricular taps or shunt placement surgery for hydrocephalus.

\section{Materials and Methods}

NGF concentrations were determined in CSF aliquots obtained during 65 clinically warranted sampling procedures of 42 children with hydrocephalus (19 girls, 23 boys). Fourteen of these 42 hydrocephalus patients underwent surgery-related CSF sampling more than once (5 patients three times, 2 patients four and five times). CSF samples of 22 children undergoing lumbar puncture for unrelated reasons (i.e. exclusion of meningitis after a febrile convulsion) served as controls ( 8 girls, 14 boys). After centrifugation for $15 \mathrm{~min}$. at $2500 \mathrm{rpm}$, samples were aliquoted, frozen and stored at $-80^{\circ} \mathrm{C}$ until analysis. The chronological age at the time of sampling was similar in hydrocephalus patients (median/range 0.4/0-14.3 years) and controls $(0.9 / 0-13.1$ years, $p=0.284)$. In 31/ 65 hydrocephalus samples (47.7\%) and 11/22 controls (50\%), the volume of CSF available also allowed for determination of NT-3 concentrations.
All sampling procedures were performed as clinically indicated, and all investigational analyses were performed in excess material. The study was approved by the ethical committee of the Ludwig-Maximilians-University, $\mathrm{Mu}-$ nich.

Hydrocephalus was congenital in 22/42 children (52.4\%; 9 suffering from spinal dysraphism with Arnold Chiari II malformation, 13 from cerebral malformations without spinal dysraphism) and acquired in 20/42 children (47.6\%; 15 premature newborns with intraventricular hemorhage, 3 chronic subdural hematoma, 2 posterior fossa tumors). Patients had evidence of ventricular dilatation by cerebral computed tomography, magnetic resonance imaging and/or ultrasound scans obtained before surgery and showed clinical symptoms of increased ICP, such as vomiting, bulging fontanel, rapidly increasing head circumference, lethargy, headaches, papilledema and seizures. ICP during sampling was found to be elevated in 58 cases ( $89 \%$ ) and normal or near-normal in 7 cases (11\%).

Bacteria were cultured from $8 / 65$ hydrocephalus samples (12.3\%) while all control CSF samples proved sterile. Patients and controls did not have a history of autoimmune or progressive malignant disease. None of the control children had evidence of cerebral malformation.

NGF and NT-3 concentrations were determined in triplicate in undiluted CSF by commercially available sandwich-type enzyme-linked immunosorbent assays (Promega, Madison, Wisconsin, USA) following the manufacturer's instructions. The coefficients of variance for intra-assay variability were $4.4 \%$ and $5.2 \%$ for NGF and NT-3, respectively, and the detection limit was $1 \mathrm{pg} /$ $\mathrm{mL}$ for both assays. Inter-group comparisons of measurements were performed by the Mann-Whitney U test. Categorical data were compared by the $\mathrm{X}^{2}$ test, using Fisher exact values if at least one expected cell value was below 5 . The Spearman rank order test was employed to assess bivariate correlations. Significance was assumed for $\mathrm{p}<0.05$ in all statistical tests used.

\section{Results}

NGF and NT-3 concentrations were greatly elevated in hydrocephalus CSF samples, as compared to controls (Fig. 1, Fig. 2). Median (range) NGF concentrations were $225(<1-2025) \mathrm{pg} / \mathrm{mL}$ in hydrocephalic samples, compared to $4(<1-68) \mathrm{pg} / \mathrm{mL}$ in controls $(\mathrm{p}<0.001)$. NGF was undetectable or low $(<10 \mathrm{pg} / \mathrm{mL})$ in $9 / 65$ hydrocephalus samples (14\%), as compared to $14 / 22$ controls $(64 \%)(\mathrm{p}<0.001)$. NT-3 was undetectable $(<1 \mathrm{pg} / \mathrm{mL})$ in 17/31 hydrocephalic CSF samples (54.8\%) and in all 11 control CSF samples assayed $(\mathrm{p}=0.009)$. As summarised in Table 1, CSF protein concentrations were also el- 


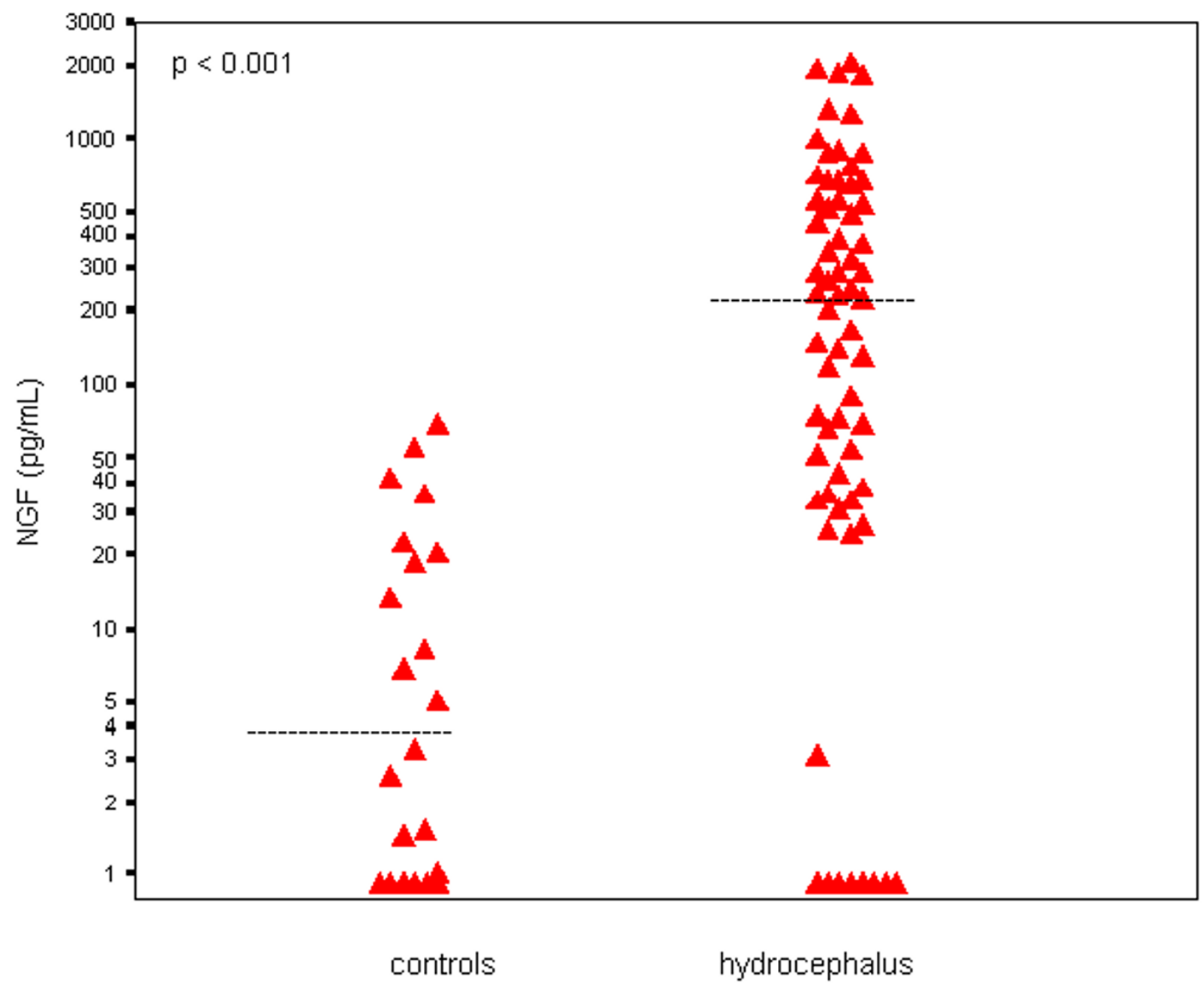

Figure I

NGF concentrations (logarithmic scale) in CSF samples of infants and children with hydrocephalus (right, $n=65)$ and controls (left, $n=22$ ). Horizontal bars denote median.

evated in hydrocephalus CSF samples (median/range 248/14-1284 mg/dL) as compared to controls (24/17$100 \mathrm{mg} / \mathrm{dL}, \mathrm{p}<0.001)$ but $\mathrm{NGF} /$ protein ratios were higher in hydrocephalic samples, as compared to controls $(p=0.017)$. In hydrocephalic CSF samples, there was a positive association between NGF and NT-3 $\left(\mathrm{R}_{\mathrm{S}}=\right.$ $0.456, \mathrm{p}=0.010)$ and NT- 3 and protein $\left(\mathrm{R}_{\mathrm{S}}=0.432, \mathrm{p}=\right.$ $0.031)$ but not between NGF and protein $\left(R_{s}=0.082\right.$, $p$ $=0.545)$. There was also no relationship between NGF and protein in control CSF samples $\left(\mathrm{R}_{\mathrm{S}}=-0.27, \mathrm{p}=\right.$ 0.904). Neither NGF nor NT-3 were related to chronological age in either hydrocephalus or control CSF samples ( $p>0.1$ ). In contrast, CSF protein showed a negative relationship to age in controls $\left(R_{s}=-0.744, p<0.001\right)$ but not in hydrocephalic samples $\left(\mathrm{R}_{\mathrm{S}}=-0.108, \mathrm{p}=\right.$ 0.423).
Table I: Comparison of hydrocephalus and control CSF samples

\begin{tabular}{llll}
\hline & Hydrocephalus & Controls & $P$ \\
\hline & & & \\
Age $($ years $)$ & 65 & 22 & \\
Protein $(\mathrm{mg} / \mathrm{dL})$ & $0.4(0-14.3)$ & $0.9(0-13.1)$ & $>0.1$ \\
NGF $(\mathrm{pg} / \mathrm{mL})$ & $248(14-1284)$ & $24(17-100)$ & $<0.001$ \\
NGF/protein ratio & $225(<1-2025)$ & $4.1(<1-68)$ & $<0.001$ \\
& $1.04(0.04-59.09)$ & $0.22(0.02-$ & 0.017 \\
Low NGF $(<10 \mathrm{pg} / \mathrm{mL})$ & $9(14 \%)$ & $3.78)$ & \\
Undetectable NT-3 & $17 / 31$ & $14(64 \%)$ & $<0.001$ \\
& & $11 / 11$ & 0.007
\end{tabular}




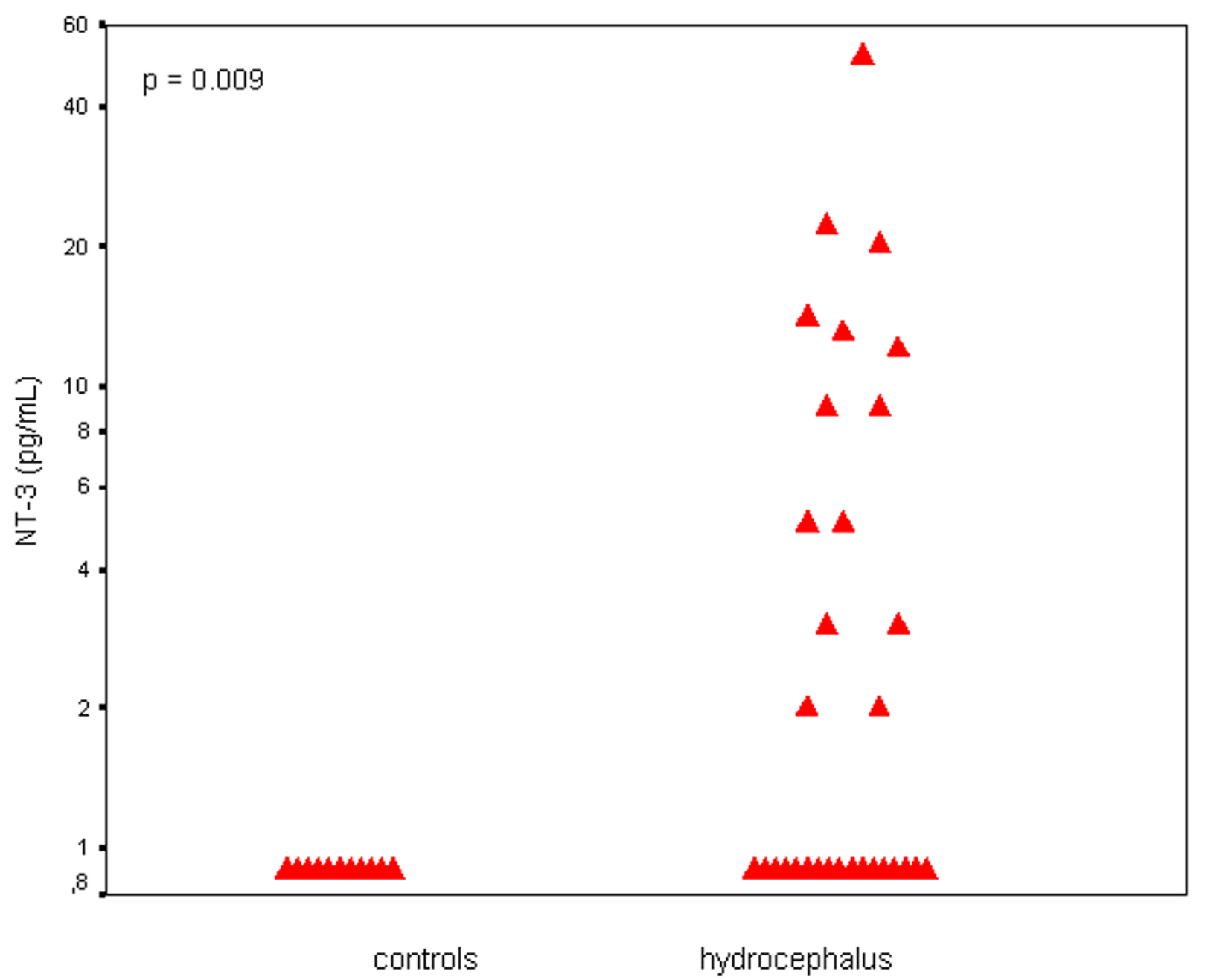

Figure 2

NT-3 concentrations (logarithmic scale) in CSF samples of infants and children with hydrocephalus (right, $\mathrm{n}=3 \mathrm{I}$ ) and controls (left, $\mathrm{n}=\mathrm{II}$ ).

NGF and NT-3 concentrations did not differ between samples from patients with congenital or acquired hydrocephalus (Table 2). Also, bacterial infection was not associated with significant differences of NGF or NT-3 concentrations. NGF and NT-3 concentrations were similar in first and repeat CSF samples, and no significant differences emerged between samples with elevated and near-normal pressure at the time of CSF sampling (Table 2).

When CSF samples were grouped according to the patients' symptoms, NGF concentrations in CSF of children complaining of headaches were higher than in those without headaches (Table 3). In contrast, there was little or no correlation between NGF or NT-3 concentrations in the CSF of hydrocephalic children presenting or not presenting with other clinical signs of elevated ICP such as vomiting, lethargy, bulging anterior fontanel or rapidly expanding head circumference (Table 3). However, the uneven distribution of chronological age between groups defined by these symptoms precluded further analysis. Nine hydrocephalus samples (14\%), as compared to $14 / 22$ controls (64\%), had undetectable or very low $(<10 \mathrm{ng} / \mathrm{mL})$ NGF concentrations. This group did not differ from those with NGF $>10 \mathrm{pg} / \mathrm{mL}$ with respect to age $(p>0.1)$ or CSF protein concentrations ( $p>0.1)$. Low NGF concentrations were never observed in children complaining about headaches, those with acute papilledema, and those who did not have an open bulging fontanel (Table 3). 
Table 2: Comparison of hydrocephalus CSF samples grouped according to clinical characteristics

\begin{tabular}{|c|c|c|c|}
\hline & Congenital & Acquired & $P$ \\
\hline $\mathrm{n}$ & 30 & 35 & \\
\hline Age (years) & $0.35(0-14.3)$ & $0.4(0-1 \mathrm{I} .2)$ & $>0.1$ \\
\hline Protein $(\mathrm{mg} / \mathrm{dL})$ & $271(36-853)$ & $203(14-1284)$ & $>0.1$ \\
\hline NGF (pg/mL) & $149(<1-2025)$ & $238(<1-1876)$ & $>0.1$ \\
\hline NGF/protein ratio & $1.03(0.04-14.82)$ & $1.04(0.05-59.09)$ & $>0.1$ \\
\hline Low NGF (< 10 pg/mL) & $5(17 \%)$ & $4(11 \%)$ & $>0.1$ \\
\hline \multirow[t]{2}{*}{ Undetectable NT-3 } & $6 / 17$ & $11 / 14$ & 0.029 \\
\hline & Cultures positive & Cultures negative & $\mathrm{P}$ \\
\hline$n$ & 8 & 57 & \\
\hline Age (years) & $0.35(0.1-2.4)$ & $0.4(0-14.3)$ & $>0.1$ \\
\hline Protein $(\mathrm{mg} / \mathrm{dL})$ & $24 I(88-1100)$ & $248(14-1284)$ & $>0.1$ \\
\hline NGF $(\mathrm{pg} / \mathrm{mL})$ & $473(43-2025)$ & $200(<1-1876)$ & $>0.1$ \\
\hline NGF/protein ratio & $0.96(0.20-7.47)$ & $1.04(0.04-59.09)$ & $>0.1$ \\
\hline Low NGF $(<10 \mathrm{pg} / \mathrm{mL})$ & $0(0 \%)$ & $9(16 \%)$ & $>0.1$ \\
\hline \multirow[t]{2}{*}{ Undetectable NT-3 } & $2 / 2$ & $15 / 29$ & $>0.1$ \\
\hline & First sample & Repeat sample & $\mathrm{P}$ \\
\hline$n$ & 42 & 23 & \\
\hline Age (years) & $0.4(0-14.3)$ & $0.3(0-11.2)$ & $>0.1$ \\
\hline Protein $(\mathrm{mg} / \mathrm{dL})$ & $251(15-1100)$ & $210(14-1284)$ & $>0.1$ \\
\hline NGF (pg/mL) & $149(<1-2025)$ & $279(<1-1876)$ & $>0.1$ \\
\hline NGF/protein ratio & $0.98(0.07-59.09)$ & $1.07(0.04-16.43)$ & $>0.1$ \\
\hline Low NGF $(<10 \mathrm{pg} / \mathrm{mL})$ & $7(17 \%)$ & $2(9 \%)$ & $>0.1$ \\
\hline \multirow[t]{2}{*}{ Undetectable NT-3 } & $9 / 19$ & $8 / 12$ & $>0.1$ \\
\hline & Pressure low & Pressure elevated & $\mathrm{P}$ \\
\hline $\mathrm{n}$ & 7 & 58 & \\
\hline Age (years) & I.I $(0.1-4.8)$ & $0.3(0-14.3)$ & $>0.1$ \\
\hline Protein $(\mathrm{mg} / \mathrm{dL})$ & $149(15-467)$ & $253(14-1284)$ & $>0.1$ \\
\hline NGF (pg/mL) & $87(<1-886)$ & $234(<-2025)$ & $>0.1$ \\
\hline NGF/protein ratio & $0.50(0.20-59.09)$ & $1.07(0.04-16.43)$ & $>0.1$ \\
\hline Low NGF $(<10$ pg/mL) & I (14\%) & $8(14 \%)$ & $>0.1$ \\
\hline Undetectable NT-3 & $2 / 3$ & $15 / 28$ & $>0.1$ \\
\hline
\end{tabular}

\section{Discussion}

The present study indicates elevated concentrations of the neurotrophins NGF and NT-3 in the CSF of hydrocephalic children. NGF concentrations in most hydrocephalus CSF samples exceeded published serum reference concentrations, [10-12] suggesting intrathecal NGF production in hydrocephalic children. Astrocytes and oligodendrocytes can be induced to secrete NGF and
NT-3 $[13,14]$, and these cells are the most likely the source of NGF and NT-3 in CSF. Since NGF and NT-3 CSF concentrations were also related to overall CSF protein levels in hydrocephalic children, some of the NGF and NT-3 molecules detected in CSF may actually be derived from neurotrophins circulating in the blood. However, NGF/protein ratios in hydrocephalus samples by far exceeded those in controls, lending further support to 
Table 3: Comparison of hydrocephalus CSF samples grouped according to the patients' symptoms.

\begin{tabular}{|c|c|c|c|}
\hline \multicolumn{4}{|c|}{ Headache } \\
\hline & Yes & no & $\mathrm{P}$ \\
\hline $\mathrm{n}$ & 9 & 56 & \\
\hline Age (years) & $1.8(1.0-7.6)$ & $0.3(0-14.3)$ & $<0.001$ \\
\hline Protein $(\mathrm{mg} / \mathrm{dL})$ & $388(93-833)$ & $211(14-1284)$ & $>0.1$ \\
\hline NGF $(\mathrm{pg} / \mathrm{mL})$ & $498(163-1815)$ & $|4|(<1-2025)$ & 0.022 \\
\hline NGF/protein ratio & $1.20(0.78-3.32)$ & $0.82(0.04-59.09)$ & $>0.1$ \\
\hline Low NGF $(<10 \mathrm{pg} / \mathrm{mL})$ & $0(0 \%)$ & $15(27 \%)$ & $>0.1$ \\
\hline Undetectable NT-3 & $\mathrm{I} / 4$ & $16 / 27$ & $>0.1$ \\
\hline \multicolumn{4}{|c|}{ Acute papilledema } \\
\hline & Yes & No & $\mathrm{P}$ \\
\hline $\mathrm{n}$ & 4 & 61 & \\
\hline Age (years) & $3.3(1.8-5.0)$ & $0.3(0-14.3)$ & 0.014 \\
\hline Protein $(\mathrm{mg} / \mathrm{dL})$ & $273(98-638)$ & $248(14-1284)$ & $>0.1$ \\
\hline NGF $(\mathrm{pg} / \mathrm{mL})$ & $432(225-548)$ & $200(<1-2025)$ & $>0.1$ \\
\hline NGF/protein ratio & $1.78(0.78-3.32)$ & $1.0(0.04-59.09)$ & $>0.1$ \\
\hline Low NGF $(<10 \mathrm{pg} / \mathrm{mL})$ & $0(0 \%)$ & $9(15 \%)$ & $>0.1$ \\
\hline Undetectable NT-3 & $0 / 1$ & $7 / 20$ & $>0.1$ \\
\hline \multicolumn{4}{|c|}{ Decreased consciousness } \\
\hline & Yes & No & $\mathrm{P}$ \\
\hline $\mathrm{n}$ & 16 & 49 & \\
\hline Age (years) & $1.8(0.1-14.3)$ & $0.2(0-7.6)$ & $<0.001$ \\
\hline Protein $(\mathrm{mg} / \mathrm{dL})$ & $251(47-822)$ & $211(14-1284)$ & $>0.1$ \\
\hline NGF (pg/mL) & $280(<1-1815)$ & $200(<1-2025)$ & $>0.1$ \\
\hline NGF/protein ratio & $2.30(0.05-9.43)$ & $0.63(0.04-59.09)$ & $>0.1$ \\
\hline Low NGF $(<10 \mathrm{pg} / \mathrm{mL})$ & I $(6 \%)$ & $8(16 \%)$ & $>0.1$ \\
\hline Undetectable NT-3 & $3 / 6$ & $14 / 25$ & $>0.1$ \\
\hline \multicolumn{4}{|c|}{ Bulging fontanel } \\
\hline & Yes & No & $\mathrm{P}$ \\
\hline $\mathrm{n}$ & 44 & 21 & \\
\hline Age (years) & $0.2(0-5.10)$ & $3.3(0-14.3)$ & $<0.001$ \\
\hline Protein $(\mathrm{mg} / \mathrm{dL})$ & $251(36-1284)$ & $210(14-853)$ & $>0.1$ \\
\hline NGF (pg/mL) & $122(<1-2025)$ & $365(25-1815)$ & 0.054 \\
\hline NGF/protein ratio & $0.59(0.04-14.82)$ & $2.30(0.09-59.09)$ & $>0.1$ \\
\hline Low NGF $(<10 \mathrm{pg} / \mathrm{mL})$ & $9(20 \%)$ & $0(0 \%)$ & 0.048 \\
\hline Undetectable NT-3 & $13 / 2 \mid$ & $4 / 10$ & $>0.1$ \\
\hline \multicolumn{4}{|c|}{ Vomiting } \\
\hline & Yes & No & $\mathrm{P}$ \\
\hline $\mathrm{n}$ & 35 & 30 & \\
\hline Age (years) & $0.5(0-11.2)$ & $0.2(0-14.3)$ & 0.083 \\
\hline Protein $(\mathrm{mg} / \mathrm{dL})$ & $334(47-853)$ & $187(14-1284)$ & $>0.1$ \\
\hline NGF $(\mathrm{pg} / \mathrm{mL})$ & $129(<1-2025)$ & $331(<1-1876)$ & $>0.1$ \\
\hline NGF/protein ratio & $0.61(0.05-7 . .47)$ & $1.72(0.04-59.09)$ & 0.028 \\
\hline
\end{tabular}


Table 3: Comparison of hydrocephalus CSF samples grouped according to the patients' symptoms. (Continued)

\begin{tabular}{|c|c|c|c|}
\hline Low NGF $(<10 \mathrm{pg} / \mathrm{mL})$ & $9(13 \%)$ & $4(14 \%)$ & $>0.1$ \\
\hline Undetectable NT-3 & $5 / 12$ & $12 / 19$ & $>0.1$ \\
\hline \multicolumn{4}{|c|}{ Widening skull sutures } \\
\hline & Yes & No & $\mathrm{P}$ \\
\hline $\mathrm{n}$ & 42 & 23 & \\
\hline Age (years) & $0.1(0-5.1)$ & $2.4(0.1-14.3)$ & $<0.001$ \\
\hline Protein $(\mathrm{mg} / \mathrm{dL})$ & $248(36-1284)$ & $224(14-853)$ & $>0.1$ \\
\hline NGF (pg/mL) & $102(<1-2025)$ & $365(<1-1815)$ & 0.052 \\
\hline NGF/protein ratio & $0.57(0.04-14.82)$ & $2.45(<1-59.09)$ & 0.028 \\
\hline Low NGF $(<10 \mathrm{pg} / \mathrm{mL})$ & $7(17 \%)$ & $2(9 \%)$ & $>0.1$ \\
\hline Undetectable NT-3 & $13 / 20$ & $4 / 11$ & $>0.1$ \\
\hline \multicolumn{4}{|c|}{ Increasing head circumference } \\
\hline & Yes & No & $\mathrm{P}$ \\
\hline $\mathrm{n}$ & 47 & 18 & \\
\hline Age (years) & $0.3(0-7.6)$ & $2.35(0-14.3)$ & 0.028 \\
\hline Protein $(\mathrm{mg} / \mathrm{dL})$ & $27 \mid(36-1284)$ & $139(14-680)$ & 0.025 \\
\hline NGF (pg/mL) & $238(<1-2025)$ & $180(<1-1772)$ & $>0.1$ \\
\hline NGF/protein ratio & $0.78(0.04-14.82)$ & $2.65(0.19-59.09)$ & 0.034 \\
\hline Low NGF $(<10 \mathrm{pg} / \mathrm{mL})$ & $6(13 \%)$ & $3(17 \%)$ & $>0.1$ \\
\hline Undetectable NT-3 & $13 / 21$ & $4 / 10$ & $>0.1$ \\
\hline
\end{tabular}

the notion of intrathecal NGF production. As proteins are mainly cleared from CSF by lumbar drainage, neurotrophins released into the CSF of children with acute hydrocephalus will be retained as long as the impaired drainage persists.

While our investigation demonstrates increased NGF and NT-3 CSF concentrations in a considerable proportion of infants and children with hydrocephalus, the association of this finding with elevated intracranial pressure is not formally proven and therefore remains hypothetical. We assume that the NGF and NT-3 concentrations measured are probably a reflection of the average pressure increase over several days rather than the actual pressure at the time the sample was taken. Ideally, determinations of NGF and NT-3 in simultaneously drawn ventricular (and possibly lumbar) CSF and in peripheral blood would be appropriate to answer questions as to the origin of the neurotrophins measured. Gradients between spinal and ventricular CSF in various protein and other metabolic factors certainly exist depending on the underlying disease [15], but due to ethical reasons no other control group was available.
Recently, proteins associated with cell death such as soluble Fas and the brain specific neurofilament triplet protein, glial fibrillary acidic protein and S-10o were found in the CSF of hydrocephalic children reflecting ongoing neurodegeneration $[16,17]$. Since the neurotrophins NGF and NT-3 are known to be involved in the regulation of survival and differentiation of neurons, they may play a role for the recovery of damaged nerve cells in children with elevated ICP.

Death of hippocampal neurons after transient cerebral ischaemia may be delayed by intraventricular injection of NGF in rodents, [18-20] although the beneficial effects of NGF administration are not unequivocal [2123]. Somatic NGF gene therapy is being investigated for treatment of brain injury in experimental animals [24]. Infusion of NGF into ventricular CSF has been attempted in patients with Alzheimer's disease [25] but side-effects consisting of dull, constant back pain occurred. Interestingly, hydrocephalic children complaining about headaches had higher NGF concentrations in the CSF than those who did not, while NGF concentrations were only weakly related to other clinical symptoms of increased ICP. As the group of children with hydrocephalus is quite heterogeneous with respect to etiology and clinical situa- 
tion, restraint must be exerted with statistical analyses. Further clinical investigations involving well-defined subgroups may help to elucidate the relationships between clinical parameters, imaging data, and NGF/NT-3 CSF concentrations in more detail.

\section{Conclusion}

NGF and NT-3 concentrations are markedly elevated in CSF of children with hydrocephalus. We propose that increased NGF and NT-3 production represent adaptive responses of the brain to prolonged elevated ICP.

\section{Competing interests \\ none declared}

\section{Acknowledgements}

We thank Evelyn Strau $\beta$ for technical assistance with preparing the collected CSF samples for analysis.

\section{References}

I. Braun KP, van Eijsden P, Vandertop WP, de Graaf RA, Gooskens RH, Tulleken KA, Nicolay K: Cerebral metabolism in experimental hydrocephalus: an in vivo IH and $3 \mathrm{IP}$ magnetic resonance spectroscopy study. J Neurosurg 1999, 91:660-668

2. Tashiro Y, Chakrabortty S, Drake JM, Hattori T: Progressive loss of glutamic acid decarboxylase, parvalbumin, and calbindin D28K immunoreactive neurons in the cerebral cortex and hippocampus of adult rat with experimental hydrocephalus. J Neurosurg 1997, 86:263-27|

3. Cohen RI, Marmur R, Norton WT, Mehler MF, Kessler JA: Nerve growth factor and neurotrophin-3 differentially regulate the proliferation and survival of developing rat brain oligodendrocytes. I Neurosci 1996, 16:6433-6442

4. Miyajima $M$, Sato $K$, Arai $H$ : Choline acetyltransferase, nerve growth factor and cytokine levels are changed in congenitally hydrocephalic HTX rats. Pediatr Neurosurg 1996, 24: I-4

5. Lindvall O, Ernfors P, Bengzon J, Kokaia Z, Smith ML, Siesjo BK, Persson $\mathrm{H}$ : Differential regulation of mRNAs for nerve growth factor, brain-derived neurotrophic factor, and neurotrophin 3 in the adult rat brain following cerebral ischemia and hypoglycemic coma. Proc Natl Acad Sci USA 1992, 89:648-652

6. DeKosky ST, Goss JR, Miller PD, Styren SD, Kochanek PM, Marion D: Upregulation of nerve growth factor following cortical trauma. Exp Neurol 1994, I 30: 173-177

7. Kossmann T, Stahel PF, Lenzlinger PM, Redl H, Dubs RW, Trentz O, Schlag G, Morganti Kossmann MC: Interleukin-8 released into the cerebrospinal fluid after brain injury is associated with blood-brain barrier dysfunction and nerve growth factor production. I Cereb Blood Flow Metab 1997, I 7:280-289

8. Mizuno Y, Takada H, Urakami K, lhara K, Kira R, Suminoe A, Ohga S, Aoki T, Hara T: Neurotrophin-3 levels in cerebrospinal fluid from children with bacterial meningitis, viral meningitis, or encephalitis. J Child Neurol 2000, I5:19-21

9. Gilmore JH, Jarskog LF, Lindgren JC, McEvoy JP, Xiao H: Neurotrophin-3 levels in the cerebrospinal fluid of patients with schizophrenia or medical illness. Psychiatry Res 1997, 73:I09-I I3

10. Murase K, Nabeshima T, Robitaille Y, Quirion R, Ogawa M, Hayashi K: NGF level is not decreased in the serum, brain-spinal fluid, hippocampus, or parietal cortex of individuals with Alzheimer's disease. Biochem Biophy Res Comm 1993, 193:198-203

II. Falcini F, Matucci Cerinic M, Ermini M, Generini S, Lombardi A, Pignone A, Leoncini G, Tirassa P, Aloe L: Nerve growth factor circulating levels are increased in Kawasaki disease: correlation with disease activity and reduced angiotensin converting enzyme levels. J Rheumatol 1996, 23:1798-1802

12. Falcini F, Matucci Cerinic M, Lombardi A, Generini S, Pignone A, Tirassa $P$, Ermini $M$, Lepore $L$, Partsch $G$, Aloe L: Increased circulating nerve growth factor is directly correlated with disease activity in juvenile chronic arthritis. Ann Rheum Dis 1996, 55:745-748
13. Micera A, Vigneti E, Aloe L: Changes of NGF presence in nonneuronal cells in response to experimental allergic encephalomyelitis in Lewis rats. Exp Neurol 1998, 154:4I-46

14. Goss JR, O'Malley ME, Zou L, Styren SD, Kochanek PM, DeKosky ST: Astrocytes are the major source of nerve growth factor upregulation following traumatic brain injury in the rat. Exp Neurol 1998, I 49:301-309

15. Gerber J, Tumani $H$, Kolenda $H$, Nau R: Lumbar and ventricular CSF protein, leukocytes, and lactate in suspected bacterial CNS infections. Neurology 1998, $51: 1710-1714$

16. Felderhoff-Müser U, Herold R, Hochhaus F, Koehne P, Ring-Mrozik E, Obladen M, Bührer C: Increased cerebrospinal fluid concentrations of soluble Fas (CD95/Apo-I) in hydrocephalus. Arch Dis Child 200I, 84:369-372

17. Whitelaw A, Rosengren L, Blennow M M: Brain specific proteins in posthaemorrhagic ventricular dilatation. Arch Dis Child Fetal Neonatal Ed 200I, 84:F90-F9l

18. Holtzman DM, Sheldon RA, Jaffe W, Cheng Y, Ferriero DM: Nerve growth factor protects the neonatal brain against hypoxicischemic injury. Ann Neurol 1996, 39:1 |4-122

19. Ishimaru H, Takahashi A, Ikarashi Y, Maruyama Y: NGF delays rather than prevents the cholinergic terminal damage and delayed neuronal death in the hippocampus after ischemia. Brain Res 1998, 789:194-200

20. Shigeno T, Mima T, Takakura K, Graham DI, Kato G, Hashimoto Y, Furukawa S S: Amelioration of delayed neuronal death in the hippocampus by nerve growth factor. J Neurosci 1991, I I:29|42919

21. Beck T, Wree A, Sauer DD: Chronic infusion of nerve growth factor does not rescue pyramidal cells after transient forebrain ischemia in the rat. Neurosci Lett 1992, 1 35:252-254

22. Kent TA, Quast M, Taglialatela G, Rea C, Wei J, Tao Z, Perez Polo JR: Effect of NGF treatment on outcome measures in a rat model of middle cerebral artery occlusion. I Neurosci Res 1999, 55:357-369

23. Koh JY, Gwag BJ, Lobner D, Choi DW: Potentiated necrosis of cultured cortical neurons by neurotrophins. Science 1995, 268:573-575

24. Andsberg G, Kokaia Z, Björklund A, Lindvall O, Martinez-Serrano A Amelioration of ischaemia-induced neuronal death in the rat striatum by NGF-secreting neural stem cells. Eur J Neurosci 1998, 10:2026-2036

25. Jönhagen Me, Nordberg A, Amberla K, Bäckman L, Ebendal T, Meyerson B, Olson L, Seiger A, Shigeta M, Theodorsson E, Viitanen M, Winblad B, Wahlund LO: Intracerebroventricular infusion of nerve growth factor in three patients with Alzheimer's disease. Dement Geriatr Cogn Disord 1998, 9:246-257

\section{Pre-publication history}

The pre-publication history for this paper can be accessed here:

http://www.biomedcentral.com/content/backmatter/ 1471-2431-1-2-b1.pdf

\section{Publish with BioMed Central and every} scientist can read your work free of charge

$$
\begin{aligned}
& \text { "BioMedcentral will be the most significant development for } \\
& \text { disseminating the results of biomedical research in our lifetime." }
\end{aligned}
$$
Paul Nurse, Director-General, Imperial Cancer Research Fund

Publish with BMC and your research papers will be: - available free of charge to the entire biomedical community - peer reviewed and published immediately upon acceptance - cited in PubMed and archived on PubMed Central

- yours - you keep the copyright

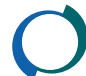
BioMedcentral.com http://www.biomedcentral.com/manuscript/ editorial@biomedcentral.com 